\title{
Effect of environmental quality and mesohabitat structure on a Biotic Integrity Index based on fish assemblages of cerrado streams from Rio Cuiabá basin, Brazil
}

\author{
Machado, NG. ${ }^{a, c *}$, Venticinque, EM. ${ }^{b}$ and Penha, J. \\ aLaboratório de Biologia da Conservação - LABIC, Instituto Federal de Mato Grosso - IFMT, \\ Campus Cuiabá Bela Vista, CEP 78050-560, Cuiabá, MT, Brazil \\ 'Departamento de Botânica, Ecologia e Zoologia, Centro de Biociências, \\ Universidade Federal do Rio Grande do Norte - UFRN, Campus Universitário Lagoa Nova, CEP 59072-970, Natal, RN, Brazil \\ 'Pós-graduação em Ecologia e Conservação da Biodiversidade, Universidade Federal de Mato Grosso - UFMT, \\ CEP 78060-900, Cuiabá, MT, Brazil \\ *e-mail: nadja.machado@blv.ifmt.edu.br
}

Received May 14, 2010 - Accepted September 13, 2010 - Distributed August 31, 2011

(With 2 figures)

\begin{abstract}
Over the last 30 years, the Cerrado has been experiencing various antropic impacts that have brought about alterations to species composition, structure and functioning of aquatic habitats. Therefore, studies on negative impacts are useful to prevent future damage and restore environmental quality. The objectives of our study were: i) to adapt an index of biotic integrity of streams in the Rio Cuiabá Basin and ii) to analyze if the Index of Biotic Integrity (IBI) correlated with the environmental quality measured by the Index of Environmental Quality (IEQ) and with the mesohabitat structure. We sampled 26 streams in sub-basins of the Cuiabá River. In each stream, we closed a stretch of $50 \mathrm{~m}$ with blockage nets and used electrofishing to capture fish. To obtain a measure of environmental quality in sampled units, we characterized the stream and its micro basin. For the analyses, we used the Spearman Correlation, Kruskal-Wallis test and Analysis of Multiple Regression. We collected 697 individuals distributed into 6 orders, 15 families and 49 species. The IBI followed changes on environmental quality measured by IEQ when we removed streams that present natural barriers from the analysis $\left(r^{2}=0.4 ; r^{2}=0.58\right)$. Types of land use did not affect the biotic integrity $(n=26 ; d f=4 ; H=4,860$; $\mathrm{p}=0.302)$, but natural and artificial barriers affected it $(\mathrm{n}=26 ; \mathrm{df}=4 ; \mathrm{H}=11,027 ; \mathrm{p}=0.026)$. The IBI was not sensitive to variations in mesohabitat structure $\left(\mathrm{F}_{2,23}=0.373 ; \mathrm{r}^{2}=0.031\right.$; Axe $1 \mathrm{p}=0.620$; Axe $\left.2 \mathrm{p}=0.490\right)$. The IBI is certainly a reasonable instrument for evaluating changes in the environment, but we cannot ignore the fact that we were able to obtain the same result with any combinations of metrics. This makes its analysis and interpretation difficult.
\end{abstract}

Keywords: environmental quality, headwaters, ecosystems health, fish community, agriculture, land use, aquatic ecosystems.

\section{Efeito da qualidade ambiental e da estrutura do meso-habitat sobre um índice de integridade biótica baseado em assembleias de peixes de córregos de cerrado da bacia do rio Cuiabá, Brasil}

\section{Resumo}

Nos últimos 30 anos, o cerrado tem sofrido severos impactos antrópicos que provocam alterações na composição de espécies, na estrutura e no funcionamento de habitats aquáticos. Dessa forma, estudos sobre impactos negativos são úteis para prevenir futuras degradações e restaurar a qualidade ambiental. Os objetivos do nosso estudo foram: i) adaptar um índice de integridade biótica para os riachos da bacia do rio Cuiabá e ii) analisar se o índice de integridade biótica (IIB) é correlacionado com a qualidade ambiental medida pelo índice de qualidade ambiental (IQA) e com a estrutura do meso-habitat. Amostramos 26 riachos da sub-bacia do rio Cuiabá; em cada um deles, delimitados um segmento de $50 \mathrm{~m}$, utilizando a pesca elétrica como método de coleta. Para obter a medida de qualidade ambiental nas unidades amostradas, caracterizamos os riachos e sua microbacia. Para as análises nós usamos a correlação de Sperman, o teste Kruskal-Wallis e a análise de componentes principais. Coletamos 697 indivíduos distribuídos em 6 ordens, 15 famílias e 49 espécies. O IIB seguiu mudanças na qualidade ambiental medida pelo IQA quando nós removemos da análise os riachos que apresentavam barreiras ambientais $\left(r^{2}=0.4 ; r^{2} S=0.58\right)$. Tipos de usos da terra não afetaram a integridade biótica ( $\mathrm{n}=26$; $\mathrm{df}=4 ; \mathrm{H}=4,860 ; \mathrm{p}=0.302)$, de modo oposto existiu uma associação negativa entre a presença de barreira e o IIB $(n=26 ; d f=4 ; H=11,027 ; p=0.026)$. O IIB não foi sensível às variações na estrutura do meso-habitat $\left(\mathrm{F}_{2,23}=0.373 ; \mathrm{r}^{2}=0.031\right.$; Axe $1 \mathrm{p}=0.620$; Axe $\left.2 \mathrm{p}=0.490\right)$. O IIB mostrou-se como um razoável instrumento para avaliar as mudanças do ambiente, mas não podemos ignorar que com várias combinações das métricas podemos obter um mesmo resultado, o que dificulta sua análise e interpretação.

Palavras-chave: qualidade ambiental, riachos de cabeceira, saúde ambiental, comunidade de peixes, agricultura, usos do solo, ecossistemas aquáticos. 


\section{Introduction}

The Cerrado is the second largest Brazilian biome, occupying originally almost 2 million of square meters (Ratter et al., 1997), made up of woodlands, savannas, grasslands, and gallery and dry forests (Klink and Machado, 2005). In addition, the headwaters for the main tributaries of the Paraguay and São Francisco River Basins, as well as some tributaries of the Amazonian Basin are in the Cerrado. Over the last 30 years, fifty percent in Cerrado have experienced severe antropic impacts (Jepson, 2005). This degradation occurred mainly due to the modernization of agriculture and expansion of its area (Ratter et al., 1997). The conversion of the Cerrado to simplified systems has brought about alterations to the diversity, structure and functioning of aquatic habitats (Wantzen et al., 2006).

The removal of native vegetation changes the hydrological cycle (Oliveira et al., 2005), the energy and material inputs (Allan, 1995), and erosion and deposition processes in streams (Church, 2002; Wiens, 2002) with negative consequences for fish assemblages in these streams (Faush et al., 2002). In this context, the aquatic biota depends on processes that operate on large scales that create and maintain heterogeneous habitats to complete their life history on smaller scales (Allan, 2004; Fausch et al., 2002). On a local scale, removing native vegetation and building artificial barriers as dams have restricted fish movement and this affects population viability (Pichon et al., 2006; Schlosser, 1995) and, consequently the biotic integrity of streams, altering the resilience and functioning of aquatic systems (Pringle, 2003; Vugteveen et al., 2006).

Ecological indicators (EI) are used to establish the degree of biotic integrity of the system and negative effects (Vugteveen et al., 2006; Karr et al., 1986). The first indicators were based on the presence of species or on simple characteristics of the community of a determined group of organisms. However in 1981, James Karr proposed the use of several characteristics of a fish community to evaluate biotic integrity by developing the Index of Biotic Integrity (IBI) (Niemi and McDonald, 2004).

To compose the IBI, it is advantageous to use a fish community because it occupies a high position in the trophic chain, its populations are relatively stable, it has the potential to integrate various aspects of the habitat on multiples scales, and it allows a temporal evaluation of stream conditions (Karr et al., 1986). It is important to emphasize that fish are present in conserved, as well as polluted places and results of the studies can be directly reported to authorities because they are easily assimilated (Galuch, 2007).

The power of detecting impacts by IBI is due to its ecological base as it consists of various metric values that describe the community in terms of number of taxa, tolerance to human impacts, reproduction and feeding habits (Angermeier and Karr, 1994).

An ecosystem is conserved when it has the capacity of supporting and maintaining a balanced, integrated and adaptative community of organisms with a composition, diversity and organization of species comparable to natural habitats of the region (Karr et al., 1986). To differentiate the conserved stage from the degraded stage, it is necessary to establish a reference condition. Therefore, IBI metric values are defined by comparing them to the expected value of a place in the same geographic region and of the same size where there is little or no human influence (Karr et al., 1986).

The IBI has been adapted to many regions of the world and for many ecosystems based on removing or adding metric values that compose it. Initially, the IBI was developed for rivers in the USA (Karr, 1981), and adapted to rivers in Europe (Oberdorff and Hughes, 1992), India (Ganasan and Hugges, 1998), Africa (Toham and Teugeks, 1999), Central America (Lyons et al., 1995), South America (Rodríguez-Olarte et al., 2006), and New Zealand (Joy and Death, 2004). There are also adaptations to marine (Jameson et al., 2001), estuarine (Weisberg et al., 1997), lacustrine (Karr and Dionne, 1991) and terrestrial (Kimberling et al., 2001) environments, as well as adaptations that incorporate other elements of the aquatic biota such as benthonic macro invertebrates (Stribling et al., 1998; Kerans and Karr, 1994), algae (Hill et al., 2000), amphibians (Micacchion, 2002) and plants (Ferreira et al., 2005).

Expanding the application of the IBI associated to studies with environmental quality descriptors such as water quality, physical habitat structure and the life history of land use (Oberdorff et al., 2002) is abundant (Angermeier and Davideanu, 2004; Bozzetti and Schulz, 2004; Araújo et al., 2003; Stauffer et al., 2000). From the composition of descriptors of environmental quality, an Index of Environmental Quality (IEQ) can be created that can be used to evaluate the sensitivity of the IBI to environmental changes.

The association between the IBI and the IEQ is a robust method for evaluating environmental impacts because when a channel of a stream becomes less complex, its biotic integrity decreases (Allan, 2004; Angermeier and Davideanu, 2004; Robinson et al., 2002). Therefore, the objectives of our study were: i) to adapt the biotic integrity of streams in the Rio Cuiabá Basin and ii) to analyze if there is an association between the Index of Biotic Integrity (IBI) and the Index of Environmental Quality (IEQ) and the mesohabitat structure.

\section{Material and Methods}

The Rio Cuiabá basin is located between parallels $14^{\circ} 18^{\prime}$ and $17^{\circ} 00^{\prime} \mathrm{S}$ and between meridians $54^{\circ} 40^{\prime}$ and $56^{\circ} 55^{\prime} \mathrm{W}$, totalizing approximately $29,000 \mathrm{~km}^{2}$ (Mato Grosso, 1997). Its area consists of the Pantanal plain and surrounding plateaus (Libos et al., 2005). The Rio Cuiabá is the largest affluent of the Upper River Paraguay which is the main drainage axis of the Pantanal. The greatest threats to the Pantanal come from activities in its surrounding plateaus where the headwaters are located in vegetation belonging to the Cerrado biome. The streams sampled in this study are tributaries of the Rio Cuiabá Basin and are 
located between parallels $15^{\circ}$ and $16^{\circ} \mathrm{S}$ and meridians $55^{\circ}$ and $56^{\circ} \mathrm{W}$ (Figure 1).

We sampled 26 streams of first and second order at the beginning of the dry season (June) and at the beginning of the rainy season (December), using electrofishing. In each stream, we closed a stretch of $50 \mathrm{~m}$ using blockage nets ( $6 \mathrm{~mm}$ of mesh size) to capture fish and delimit the sampled segment. To capture them, two hand nets were used, one of them connected to a Honda EU10ILP1 generator
(900 W, $110 \mathrm{~V}$, alternate current) by a multifilament $4 \mathrm{~mm}$ copper wire. We made three passages of electrofishing in each stretch sampled. Each passage took approximately 15 minutes. Collected fish were fixed in formaldehyde $10 \%$ and conserved in alcohol $70 \%$. We identified fish using Britski et al. (1999) and more up to date nomenclatures according to Reis et al. (2003). Collected species were placed in the Fish Collection of the Museu Nacional do Rio de Janeiro (MNRJ).
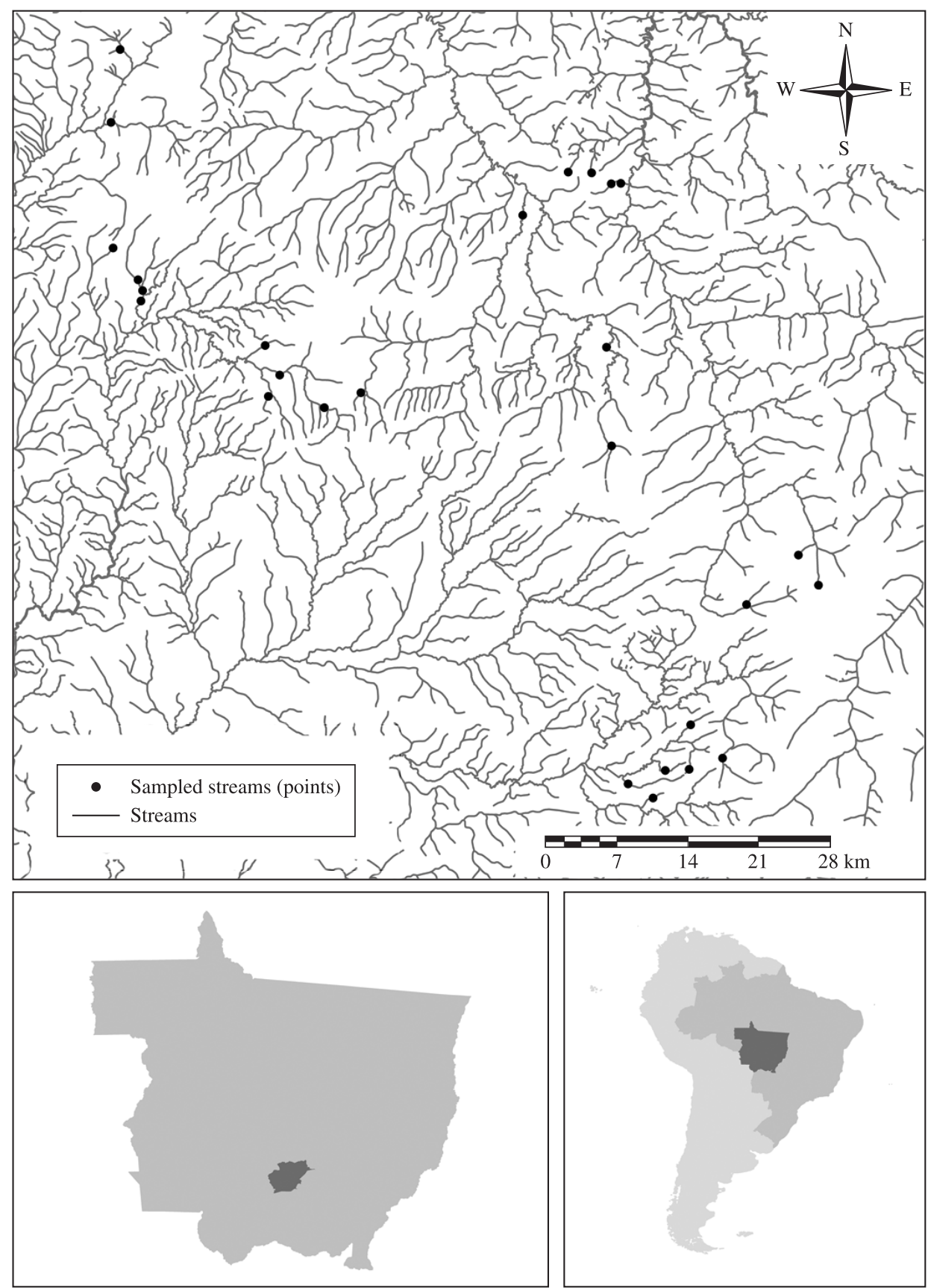

Figure 1. Localization of streams sampled in the Rio Cuiabá Basin, State of Mato Grosso, Brazil. 
To compose the Index of Environmental Quality of sampled units, we characterized both the stream and its margin. The shadow degree in each sampled unit (a stretch of $50 \mathrm{~m}$ in streams) was obtained by visual estimations done every $5 \mathrm{~m}$ and classified in the following categories: $0-10 \%, 11-60 \%$ and $60-100 \%$ of shadow. The same spatial interval was used to quantify the frequency of pools and runs. Hydrological alterations were characterized as upper river reservoir and lower river reservoir. Natural barriers were characterized as waterfalls and sinkholes (places where the stream disappeared inside the ground). Both hydrological alteration and natural barriers were obtained from information given by the neighborhood in the region. The micro basin was characterized by satellite images - bands RBG (345) of satellite LANDSAT 5 TM of 08/05 $5^{\text {th }} / 2006$ (21L) and ENVI 7.0 program. We did linear enhancing of the bands, band composition to transform to a single image, cut of micro basin supervised automatically by maximum likelihood, percentage quantification of land uses and measures of width of natural riparian forest. Land use was characterized by soil exposure (city), pasture, monoculture (Soya bean, cotton and corn), silviculture (eucalyptus) and units of conservation (UC). In UC areas, there are activities of aquatic recreation and subsistence agriculture. The percentage of land use was quantified in the micro basin area. Its area was delimited by curves of ground level. An average width of natural riparian forest in a sampled stretch was obtained by measuring three points on each side of the edge of the sampled streams.

We also measured the average width, depth and substratum type in the sampled units. A width was calculated as the medium of six transversal measures, one at every interval of $10 \mathrm{~m}$. The depth was measured using a tape, every $20 \mathrm{~cm}$ along the six points used to take measures of width. The same procedure was used to estimate the predominant substrate type in each sampled unit. The substrate type was classified into nine categories: root, trunk, gravel, sand, boulder, clay, leaf, silt and flagstone.

Reference streams were selected considering an environmental gradient from less impacted (sites with no percentage of land use by monocultures) to more impacted (sites with percentage of land use by monocultures). As in agriculture there is input of pesticides and fertilization in streams, we considered that the pasture have better conditions than agriculture. We used five reference streams - three of the first order and two of the second order. The region where we sampled streams had never been studied previously. Therefore, data from less impacted sites were used as a reference for the scoring criteria of metric values. All metric values were based on trisected lines of Karr et al. (1986).

The IBI was calculated based on designed methods by Karr et al. (1986). We considered attributes of Species Composition and Richness, Trophic Composition and Fish Abundance as biotic descriptors proposed by Karr (1981). Each attribute received a score of 5 (best condition), 3 (regular condition) and 1 (bad condition) to accompany ecological and evolutionary variations from attributes. However, we considered only information available about ecology and biology of collected fish species to compose metric values of IBI. Because of this, we did not include metric values concerning intolerance, health and reproduction. We established the trophic level for each species based on Britski et al. (1999). For some species, this information only existed at the genus level. Therefore, we used this information for the species because closely related phylogenetic species have similar ecological and biological characteristics (Table 1).

We obtained the IBI score of each stretch to add up the score of metric values for each stream. The minimum punctuation in IBI is 0 and the maximum is 8 . The higher the value, the more conserved the biota. We composed an Index of Environmental Quality (IEQ) using the following variables: pattern of land use of the micro basin; width of natural riparian forest in the sampled stretch; hydrological alteration; percentage of land use by agriculture in micro basins and proportion of runs and pools. Values of scores using the IEQ criteria vary from 0 to 1 . Its minimum punctuation is 0 and maximum is 6 . The higher the value of the IEQ, the better the environmental quality (Table 2). To facilitate the comprehension of index analyses we transformed IQE into a percentage.

To evaluate if the IBI follows changes in the environmental quality - measured by IEQ - we used Pearson's correlation analysis between the two indexes considering the significance level of $5 \%(\alpha<0.05)$. This analysis was done twice, one with 26 points and another without points that presented natural barriers totalizing 21

Table 1. Metric values and scoring criteria used to evaluate biotic integrity of streams from Rio Cuiabá Basin, Mato Grosso, Brazil.

\begin{tabular}{llccc}
\hline \multicolumn{1}{c}{ Attributes } & \multicolumn{1}{c}{ Metrics } & $\mathbf{1}$ & $\mathbf{0 . 6}$ & $\mathbf{0}$ \\
\hline Richness and & 1. Total number of families & $>5$ & $3-5$ & $1-2$ \\
Species & 2. Total number of species & $>8$ & $4-7$ & $1-3$ \\
Composition & 3. Total number of non-native species & 0 & 1 & $\geq 2$ \\
& 4. Proportional abundance of invertivore individuals & $>45 \%$ & $40-20 \%$ & $<20 \%$ \\
Trophic & 5. Proportional abundance of scraping herbivore individuals & $>5 \%$ & $5-1 \%$ & $<1 \%$ \\
Composition & 6. Proportional abundance of piscivore individuals & $>5 \%$ & $5-1 \%$ & $<1 \%$ \\
& 7. Proportional abundance of generalist individuals & $\leq 20 \%$ & $20-45 \%$ & $>45 \%$ \\
Density & 8. Number of individuals per volume & $>1.5$ & $0.5-1.49$ & $<0.49$ \\
\hline
\end{tabular}


Table 2. Categories and scoring criteria to compose IEQ from Rio Cuiabá Basin, State of Mato Grosso, Brazil.

\begin{tabular}{|c|c|c|}
\hline Attributes & Criteria & Points \\
\hline \multirow[t]{6}{*}{ Land use } & None & 1 \\
\hline & Recreation (UC) & 0.83 \\
\hline & Silviculture (eucalyptus) & 0.67 \\
\hline & Pasture & 0.50 \\
\hline & Agriculture & 0.33 \\
\hline & Exposure soil & 0 \\
\hline $\begin{array}{l}\text { Width of the } \\
\text { riparian }\end{array}$ & $>100 \mathrm{~m}$ & 1 \\
\hline \multirow[t]{5}{*}{ Forest } & $76-100 \mathrm{~m}$ & 0.83 \\
\hline & $51-75 \mathrm{~m}$ & 0.67 \\
\hline & $26-50 \mathrm{~m}$ & 0.50 \\
\hline & $1-25 \mathrm{~m}$ & 0.33 \\
\hline & $0 \mathrm{~m}$ & 0 \\
\hline \multirow{4}{*}{$\begin{array}{l}\text { Hydrological } \\
\text { alteration }\end{array}$} & None & 1 \\
\hline & Dam downstream $(\mathrm{RJ})$ & 0.75 \\
\hline & Dam upstream (RM) & 0.50 \\
\hline & $\mathrm{RJ}+\mathrm{RM}$ & 0 \\
\hline \multirow[t]{3}{*}{ Shadow } & $61-100 \%$ & 1 \\
\hline & $10-60 \%$ & 0.5 \\
\hline & $0-9 \%$ & 0 \\
\hline \multirow[t]{5}{*}{$\%$ agriculture } & None & 1 \\
\hline & $1-25 \%$ & 0.80 \\
\hline & $26-50 \%$ & 0.60 \\
\hline & $51-75 \%$ & 0.40 \\
\hline & $76-100 \%$ & 0 \\
\hline \multirow[t]{5}{*}{ Pool/Running } & $50 \%$ Pool and $50 \%$ Running & 1 \\
\hline & $>$ Pool & 0.80 \\
\hline & $>$ Running & 0.60 \\
\hline & Only pool & 0.40 \\
\hline & Only running & 0 \\
\hline
\end{tabular}

points. We did these analyses to visualize the difference, if any, caused by natural barriers in the correlation between indexes. To evaluate if natural or artificial barriers (dam downstream, dam upstream, waterfall and none) and types of land uses affected the IBI, we performed the KruskalWallis test (Zar, 1999). To evaluate the effect of mesohabitat structure on the IBI, we used a multiple regression analysis. In order to perform regression analysis, first we reduced data dimensionality of the mesohabitat matrix formed by substratum composition, average width and depth into a Principal Component Analysis (PCA). We considered the variable related to an axis when the loading of its value was $>0.6$. Then, the PCA axes were used as explanatory variables in the regression model.

\section{Results}

We collected 697 individuals distributed in 6 orders, 15 families and 49 species of fish. The order Characiform was the most abundant with 24 species $(48.98 \%)$ and 377 individuals (54.08\%), followed by orders Siluriform with 16 species $(32.65 \%)$ and 253 individuals $(32.29 \%)$ and Perciform with 5 species $(10.20 \%)$ and 34 individuals $(4.87 \%)$. Less abundant orders were the Cyprinodontiform and Gymnotiform with 2 species and 21 and 12 individuals respectively. We did not collect exotic species.

From 49 species, $22(44.90 \%)$ are shown as genera because it was not possible to identify them at the species level. The most abundant species were Astyanax asuncionensis with 95 individuals (13.63), Ancistrus sp. with 62 individuals (8.90\%), Astyanax abramis with 61 individuals (8.75\%) and Astyanax scabripinnis with 57 individuals (8.18\%) (Table 3).

In general, biotic integrity of streams sampled was low (Table 4). It was not possible to estimate the biotic integrity of two of the sampled streams as the fish had not been captured. Only 8 streams $(30.77 \%)$ presented a degree of biotic integrity larger than $60 \% ; 10(38.46 \%)$ streams presented between 59-30\% integrity; 06 (23.08\%) streams presented biotic integrity less than $29 \%$ (Table 5). Four out of five reference streams presented a degree of biotic integrity larger than $60 \%$; just one presented between $59-30 \%$ integrity.

From the streams sampled, $12(33 \%)$ did not present natural or artificial barriers; three $(11.54 \%)$ presented dams downstream from the sampled points; four (15.38\%) presented dams upstream; two (7.69\%) presented dams up and downstream; only one (3.84\%) presented sinkholes; and five $(19.23 \%)$ presented waterfalls downstream (Table 5).

Only one stream did not present natural riparian forest. Nine $(34.61 \%)$ streams presented an average width of natural riparian forest bigger than $100 \mathrm{~m}$; four $(15.38 \%)$ presented an average width between 76-100 m; five (19.23\%) presented an average width between 51-75 m; six $(23.08 \%)$ presented an average width between $26-50 \mathrm{~m}$; and one (3.84) presented an average width between $1-25 \mathrm{~m}$ (Table 5).

The biotic integrity of sampled streams measured by the IBI was sensitive to changes in the environmental quality $\left(r_{s}=0.40 ; n=26 ; p=0.04\right)$. When we removed those streams that presented waterfalls and sinkholes from the analysis, the correlation between variables increased by $45 \%\left(r_{s}=0.58 ; n=21 ; p=0.005\right)$.

Types of land use did not affect the biotic integrity $(\mathrm{N}=26 ; \mathrm{dF}=4 ; \mathrm{H}=4.860 ; \mathrm{p}=0.302)$. However, natural and artificial barriers affected the biotic integrity negatively $(\mathrm{N}=26 ; \mathrm{dF}=4 ; \mathrm{H}=11.027 ; \mathrm{p}=0.026)$. Streams without any type of barriers had the highest IBI, while those with dams up and downstream presented larger values of IBI than those that had waterfalls (Figure 2).

The IBI was not sensitive to variations in the mesohabitat structure represented by the PCA axes (Figure 3). Axis 1 captured $20.49 \%$ and axis 2 captured $18.84 \%$ of the variation of the mesohabitat structure, explaining $39.33 \%$ of the total variation. The variables boulder and average width showed 
Table 3. Species of fish and their abundances from Rio Cuiabá Basin, Mato Grosso, Brazil.

\begin{tabular}{|c|c|c|}
\hline Species & $\begin{array}{c}\text { Absolute } \\
\text { abundance }\end{array}$ & $\begin{array}{c}\text { Relative } \\
\text { abundance }\end{array}$ \\
\hline Aequidens plagiozonatus & 4 & $0.57 \%$ \\
\hline Ancistrus sp. & 62 & $8.90 \%$ \\
\hline Aphyochracinae sp. & 1 & $0.14 \%$ \\
\hline Astyanacinus moorii & 4 & $0.57 \%$ \\
\hline Astyanax abramis & 61 & $8.75 \%$ \\
\hline Astyanax asuncionensis & 95 & $13.63 \%$ \\
\hline Astyanax lineatus & 36 & $5.16 \%$ \\
\hline Astyanax scabripinnis & 57 & $8.18 \%$ \\
\hline Bryconamericus exodon & 9 & $1.29 \%$ \\
\hline Bryconops sp. & 1 & $0.14 \%$ \\
\hline Callichthys callichthys & 9 & $1.29 \%$ \\
\hline Characidium sp.1 & 4 & $0.57 \%$ \\
\hline Characidium sp.2 & 21 & $3.01 \%$ \\
\hline Cichlidae & 1 & $0.14 \%$ \\
\hline Crenicichla sp. 01 & 17 & $2.44 \%$ \\
\hline Crenicichla sp. 02 & 8 & $1.15 \%$ \\
\hline Eigemannia trilineata & 4 & $0.57 \%$ \\
\hline Gymnogeophagus balzani & 4 & $0.57 \%$ \\
\hline Gymnotus cf. carapo & 8 & $1.15 \%$ \\
\hline Hemigrammus ocellifer & 7 & $100 \%$ \\
\hline Holochestes pequira & 1 & $0.14 \%$ \\
\hline Hoplerythrinus unitaeniatus & 1 & $0.14 \%$ \\
\hline Hoplias malabaricus & 5 & $0.72 \%$ \\
\hline Hyphessobryncon sp. & 8 & $1.15 \%$ \\
\hline Hypostomus cf. cochliodon & 21 & $301 \%$ \\
\hline Jupiaba acanthogaster & 9 & $1.29 \%$ \\
\hline Knodus sp. & 36 & $5.16 \%$ \\
\hline Leporinus striatus & 2 & $0.29 \%$ \\
\hline Loricariichthys labialis & 35 & $5.02 \%$ \\
\hline Moenkhausia dichroura & 1 & $0.14 \%$ \\
\hline $\begin{array}{l}\text { Moenkhausia } \\
\text { sanctaefilomenae }\end{array}$ & 3 & $0.43 \%$ \\
\hline Odontostilbe microdon & 2 & $0.29 \%$ \\
\hline Phenacogaster jancupa & 9 & $1.29 \%$ \\
\hline Phenacogaster sp. & 1 & $0.14 \%$ \\
\hline Phenacorhamdia sp. & 7 & $1.00 \%$ \\
\hline Piabacus analis & 3 & $0.43 \%$ \\
\hline Rhamdia cf. quelen & 15 & $2.15 \%$ \\
\hline Rivulidae & 20 & $2.87 \%$ \\
\hline Rivulus punctatus & 1 & $0.14 \%$ \\
\hline Trichomycteridae sp. 1 & 19 & $2.73 \%$ \\
\hline Trichomycteridae sp. 2 & 22 & $3.16 \%$ \\
\hline Trichomycteridae sp. 3 & 7 & $1.00 \%$ \\
\hline Trichomycteridae sp. 4 & 7 & $1.00 \%$ \\
\hline Trichomycteridae sp. 5 & 20 & $2.87 \%$ \\
\hline Trichomycteridae sp. 6 & 6 & $0.86 \%$ \\
\hline Trichomycteridae sp. 7 & 7 & $1.00 \%$ \\
\hline Trichomycteridae sp. 8 & 2 & $0.29 \%$ \\
\hline Trichomycteridae sp. 9 & 13 & $1.87 \%$ \\
\hline Tatia neivai & 1 & $0.14 \%$ \\
\hline
\end{tabular}

a relationship to axis 1 and the variables boulder and silt showed a relationship to axis 2 (Table 5). The PCA result separated a group formed by streams 22, 23, 24, 25, 26, and 14 with substrate formed mainly of sand, root, and trunk. Besides sharing these characteristics, streams 12 and 16 have more vegetation. A second group was formed by stream 7 and 15 mainly with silt and boulder in substrate. The others streams did not form a clear group. There was no significant effect of axes on IBI $\left(\mathrm{F}_{2.23}=0.373 ; \mathrm{R}^{2}=0.031\right.$; axis $1 \mathrm{p}=0.620$; axis $2 \mathrm{p}=0.490)$.

\section{Discussion}

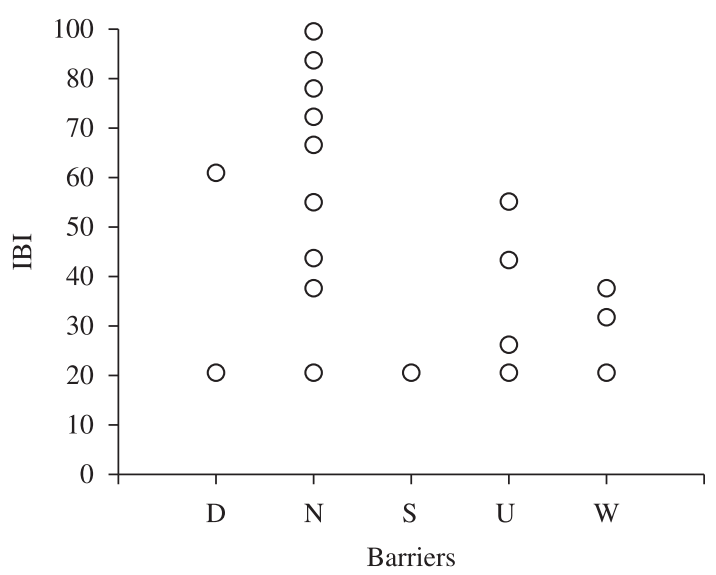

Figure 2. Effect of types of barriers on IBI of streams from Rio Cuiabá Basin, State of Mato Grosso, Brazil. N = nobarrier; $\mathrm{D}=$ dams downstream; $\mathrm{U}=$ dams upstream; $\mathrm{W}=$ waterfall; $\mathrm{S}=$ sinkhole.

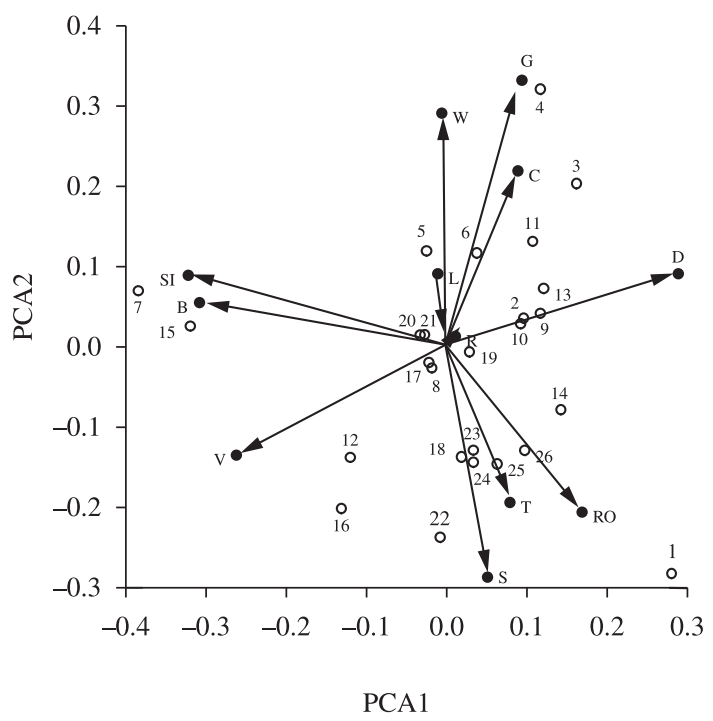

Figure 3. Results of Principal Component Analysis (PCA) scaling of 26 sampling sites (streams) based on correlation matrix of association between of environmental variables. Legend: $\mathrm{RO}=$ root; $\mathrm{T}=$ trunk; $\mathrm{G}=$ gravel; $\mathrm{SA}=$ sand; $\mathrm{B}=$ boulder; $\mathrm{C}=$ clay; $\mathrm{L}=$ leaf; $\mathrm{S}=$ silt; $\mathrm{R}=$ rock; $\mathrm{V}=$ vegetation; $\mathrm{W}=$ width; $\mathrm{D}=$ depth. 
Table 4. Biotic integrity and of environmental quality of headwater streams from Rio Cuiabá Basin, State of Mato Grosso, Brazil.

\begin{tabular}{|c|c|c|c|c|c|}
\hline Stream & IBI $(\%)$ & $\operatorname{IEQ}(\%)$ & Riparian forest & Land use & Barriers \\
\hline 22 & 88.6 & 80.5 & $>101 \mathrm{~m}$ & Unit of conservation & None \\
\hline 8 & 82.9 & 68.3 & $26-50 \mathrm{~m}$ & Pasture & None \\
\hline 11 & 82.9 & 88.8 & $76-100 \mathrm{~m}$ & Pasture & None \\
\hline 7 & 77.1 & 68.3 & $>100 \mathrm{~m}$ & Exposure soil & None \\
\hline 12 & 77.1 & 75.0 & $26-50 \mathrm{~m}$ & Pasture & None \\
\hline 17 & 71.4 & 70.5 & $26-50 \mathrm{~m}$ & Unit of conservation & None \\
\hline 16 & 65.7 & 79.5 & $51-75 \mathrm{~m}$ & Pasture & None \\
\hline 23 & 60.0 & 84.2 & $>102 \mathrm{~m}$ & Pasture & Dam downstream \\
\hline 3 & 54.3 & 22.2 & $0 \mathrm{~m}$ & Agriculture & Dam upstream \\
\hline 10 & 54.3 & 73.8 & $1-25 \mathrm{~m}$ & Pasture & None \\
\hline 9 & 42.9 & 57.3 & $51-75 \mathrm{~m}$ & Silviculture & Dam down and upstream \\
\hline 13 & 42.9 & 76.7 & $26-50 \mathrm{~m}$ & Pasture & None \\
\hline 15 & 42.9 & 68.3 & $>100 \mathrm{~m}$ & Pasture & Dam upstream \\
\hline 18 & 42.9 & 88.8 & $26-50 \mathrm{~m}$ & Unit of conservation & None \\
\hline 24 & 37.1 & 91.7 & $>103 \mathrm{~m}$ & Pasture & Waterfall \\
\hline 25 & 37.1 & 91.7 & $>104 \mathrm{~m}$ & Pasture & Waterfall \\
\hline 26 & 37.1 & 75.0 & $>105 \mathrm{~m}$ & Pasture & None \\
\hline 21 & 31.4 & 86.3 & $>100 \mathrm{~m}$ & Unit of conservation & Waterfall \\
\hline 5 & 25.7 & 56.7 & $51-75 \mathrm{~m}$ & Agriculture & Dam upstream \\
\hline 1 & 20.0 & 48.5 & $76-100 \mathrm{~m}$ & Agriculture & Dam downstream \\
\hline 4 & 20.0 & 44.3 & $76-100 \mathrm{~m}$ & Agriculture & Sinkhole \\
\hline 6 & 20.0 & 68.3 & $>100 \mathrm{~m}$ & Exposure soil & None \\
\hline 14 & 20.0 & 57.2 & $76-100 \mathrm{~m}$ & Pasture & Dam upstream \\
\hline 20 & 20.0 & 84.2 & $51-75 \mathrm{~m}$ & Unit of conservation & Waterfall \\
\hline 2 & 0.0 & 13.8 & $26-50 \mathrm{~m}$ & Agriculture & Dam down and upstream \\
\hline 19 & 0.0 & 58.3 & $51-75 \mathrm{~m}$ & Unit of conservation & Waterfall \\
\hline
\end{tabular}

Table 5. Result of Principal Components Analysis (PCA) showing variables related to environmental characteristics of headwater streams from Cuiabá River Basin, their loadings and percentage of explained variation by two axis. Bold indicates variable with loading $>0.6$.

\begin{tabular}{lcc}
\hline & Axis 1 & Axis 2 \\
\hline Root & 0,578 & 0,346 \\
Trunk & 0,392 & 0,425 \\
Gravel & $\mathbf{- 0 , 8 2 7}$ & 0,176 \\
Sand & 0,516 & 0,499 \\
Boulder & 0,206 & $\mathbf{- 0 , 7 0 1}$ \\
Clay & $-0,302$ & 0,135 \\
Leaf & 0,201 & 0,309 \\
Silt & 0,125 & $\mathbf{- 0 , 8 1 1}$ \\
Rock & 0,035 & $-0,227$ \\
Vegetation & $-0,467$ & 0,177 \\
Average depth & $-0,305$ & 0,58 \\
Average width & $\mathbf{- 0 , 7 2 1}$ & $-0,018$ \\
Explained variation \% & 20,49 & 18,84 \\
Accumulated variation \% & 20,49 & 39,33 \\
\hline
\end{tabular}

The Index of Biotic Integrity is an instrument used in various places in the world as a way to evaluate environmental impacts in aquatic communities. In most studies, the IBI was successful in detecting effects of environmental degradation in aquatic communities. These studies indicate that degradation, loss of habitat, fragmentation and pollution are the main causes of loss of the environmental integrity from streams.

The IBI from streams declined with the reduction of environmental quality estimated by the IEQ. However, although the correlation between these two indexes was significant, it was not a strong correlation $\left(r_{s}<0.75\right)$. We have two ways to explain this fact. First of all, the stronger correlations in other studies are explained by an environmental gradient along a river (a lot of points in the same river), which means no independent observations. We expected that the quantity of information increases after more observation. When observations supply the same previous information, it means that it did not increase the total amount of available knowledge (Magnusson and Mourão, 2003). 
Secondly, the not strong correlation of our work can be explained by four hypotheses. First of all, although the IBI gives an idea how distance of the original condition is the environment, it is possible that the fish assembly has been adapted to impacts that produced a low biotic integrity for reasons of historical and ecological filters such as history of three centuries of gold mining and pasture. Therefore, the answers of biota to recent impacts may be subtle. It happens, for example, when the supply conservation fishing stock has been evaluated. In this case, sometimes we find difficulties in detecting effects of fisheries or overfishing signs because of depletions long masked by improved technology, geographic expansion and exploitation of previously spurned species lower in the food web (Pauly et al., 2002). Secondly, headwater streams are systems where drastic and fast variations occur naturally, which in general makes the density of individuals and diversity less changing its standards of dominance. Thirdly, a failure in the sampling design may have occurred. There is little knowledge about the way fish from neotropical regions use the environment. If, as a few studies indicate, the spatial segregation in the habitat use was a strong and common phenomenon, or if the home range of species were very large, a stretch of 50 meters may be insufficient to have a stronger ecological pattern. If the sample unit was very small and insufficient to represent the sampled community structure, we may have captured a poor image of the communities and this makes it difficult to evaluate the details. Finally, regardless of any criticism that all indexes are susceptible, all of them are dependent on the quality of available information. Unfortunately, it was not possible to obtain information from some important metric values such as presence or absence of tolerant and intolerant species and reproductive migration. In addition to these problems, the IEQ may not have adequately captured the environmental condition that IBI responds better to.

Although Allan and Flecker (1993) point out that for ichthiofauna, the loss and transformation of the habitat is associated to the suppression of primary vegetation, it is neither this nor land use that causes negative effects on biotic integrity from the sampled streams. Data indicate that low biotic integrity can be associated to the existence of barriers instead of land use. Even those streams with the presence of riparian forests with an average width greater than $50 \mathrm{~m}$ had low environmental integrity. On the other hand, streams with the best levels of biotic integrity were those without barriers. These barriers make the colonization of streams difficult, especially in headwater streams due to declivity. In places like this, any dam causes an intensification of the geomorphologic process which can consequently alter the structure of the substratum and biota integrity.

In our study, some types of barriers are more frequent than others. However, dams up and downstream make the free movement of fish difficult (Ovidio and Philippart 2002) compromising their migration and habitat colonization. The reduction in the movement rate has severe effects when there is a negative impact on the environment and it causes local population extinction. Despite being natural barriers, waterfalls can also have a negative effect on fish populations when they are associated with aquatic recreation activities. This activity can cause a change in the stream channel due to trampling and removal of the rocky substratum. Modifications from trampling cause destabilization of the sandy substratum, which in turn causes inputs of a big quantity of sand that can homogenize the stream channel. The stream channel loses the heterogeneity of habitats, fundamental to the survival of aquatic biota. Modifications from the removal of rocky substratum also cause loss of habitat for aquatic biota, compromising the biotic integrity of streams. Sites with compromised biotic integrity cannot be colonized when there are waterfalls that make the organism fluxes difficult.

None of the sampled streams had exotic species. The presence of exotic species demonstrates that native fauna is more vulnerable to competition and predation, which can hinder the recruitment, abundance, composition and richness of native species (Meador et al., 2003). As exotic species of fish are more tolerant to environmental degradation, their presence can demonstrate that streams are more degraded (Kennard et al., 2005). In view of this, the absence of exotic species can indicate streams are not yet extremely degraded.

The IBI did not have a significant linear relationship with the mesohabitat structure described by the substratum composition, average width and depth, probably due to the degradation of streams being extremely variable and the number of sampled sites or the sampled extension being insufficient to find this relationship. It is also possible that the sampled region has previously lost its fauna. Therefore, the effect of recent impacts is difficult to be established.

However, the biotic integrity from sampled streams responds more clearly to changes caused by types of barriers than simply by types of land use. This means that, to evaluate the conservation of headwater streams by only identifying types of land use is not as efficient as when considering other attributes. This has implications with regard to the restoration and conservation of headwater streams. It is important to point out that data indicate that it is not sufficient to simply respect a minimum width of riparian forest in the Cerrado. It is necessary to review the practices of land use. The IBI is a reasonable instrument for evaluating changes in the environment, but we cannot ignore that many combinations of metric values can get the same result making its analysis and interpretation difficult. Moreover, the historical changes in the level of quality reference can make the detection of recent alterations in the biota difficult.

Acknowledgements - We gratefully acknowledge Alexandro Florentino, "Chico Bill”, Izaías Fernandes, Jaime Rufino, Luzia Lourenço da Silva, Mahmoud Mehanna and Wilhan Assunção for assistance with sampling. Specimens were collected under the legal authority of permits issued by the Secretaria de Meio Ambiente do Estado de Mato Grosso and Ministério do Meio Ambiente. This research was supported by FAPEMAT 
(4.2.2.83/02-2004-E), the Pantanal Research Center (CPP), and Brazil's Ministério da Ciência e Tecnologia (MCT). N.G.M. acknowledges a grant from CNPQ. E.M.V. acknowledges a grant from CNPQ (Proc 307997/2009-0).

\section{References}

ALLAN, JD., 2004. Landscapes and Riverscapes: the influence of land use on stream ecosystems. Annual Review of Ecology Evolution and Systematics, vol. 35, p. 257-284. http://dx.doi. org/10.1146/annurev.ecolsys.35.120202.110122

-, 1995. Stream Ecology: Structure and Function of Running Waters. Dordrecht: Kluwer. 388 p.

ALLAN, JD. and FLECKER, AS., 1993. Biodiversity conservation in running waters. BioScience, vol. 43, no. 1, p. 32-43. http:// dx.doi.org/10.2307/1312104

ANGERMEIER, PL. and KARR, JR., 1994. Biological integrity versus biological diversity as policy directives: protecting biotic resources. BioScience, vol. 44, no. 10, p. 690-697. http://dx.doi. org/10.2307/1312512

ANGERMEIER, PL. and DAVIDEANU, G., 2004. Using fish communities to assess streams in Romania: initial development of an index biotic integrity. Hydrobiologia, vol. 511, p. 65-78. http://dx.doi.org/10.1023/B:HYDR.0000014030.18386.65

ARAÚJO, FG., FICHBERG, I., PINTO, BCT. and PEIXOTO, MG., 2003. A preliminary Index of Biotic Integrity for monitoring the condition of the Rio Paraiba do Sul, Southeast Brasil. Environmental Management, vol. 32, no. 4, p. 516-526.

BOZZETTI, M. and SCHULZ, UW., 2004. An index of biotic integrity based on fish assemblages for subtropical streams in southern Brazil. Hydrobiologia, vol. 529, p. 133-144. http:// dx.doi.org/10.1007/s10750-004-5738-6

BRASIL. Ministério do Meio Ambiente, dos Recursos Hídricos e da Amazônia Legal. 1997. Plano de Conservação da Bacia do Alto Paraguai (Pantanal) - PCBAP. Diagnóstico dos Meios Físicos e Bióticos. Brasília.

BRITSKI, H.A.; SILIMON, K.Z.S.; LOPES, B.S. Peixes do Pantanal: manual de identificação. Brasília: EMBRAPA, 1999. $184 \mathrm{p}$.

CHURCH, M., 2002. Geomorphic thresholds in riverine landscape. Freshwater Biology, vol. 47, no. 4, p. 541-557. http://dx.doi. org/10.1046/j.1365-2427.2002.00919.x

FAUSCH, KD., TORGERSEN, CE., BAXTER, CV. and LI, HW., 2002. Landscapes to Riverscapes: Bridging tile Gap between Research and Conservation of Stream Fishes. BioScience, vol. 52, no. 6, p. 483-498. http://dx.doi.org/10.1641/00063568(2002)052[0483:LTRBTG]2.0.CO;2

FERREIRA, MT., RODRÍGUEZ-GONZALEZ, PM., AGUIAR, FC. and ALBUQUERQUE, A., 2005. Assessing biotic integrity in Iberian rivers: Development of a multimetric plant index. Ecological Indicators, vol. 5, no. 2, p. 137-149. http://dx.doi. org/10.1016/j.ecolind.2005.01.001

GALUCH, AV., 2007. Adaptação de um Índice de Integridade Biótica para igarapés da Amazônia Central, com base em atributos ecológicos das comunidades de peixes. Manaus: Instituto Nacional de Pesquisas da Amazônia. 38 p. Dissertação de Mestrado em Biologia de Água Doce e Pesca Interior.
GANASAN, V. and HUGHES, RM., 1998. Application of an Index of Biological Integrity (IBI) to fish assemblages of the rivers Khan and Kshipra (Madhya Pradesh), India. Freshwater Biology, vol. 40, no. 2, p. 367-383. http://dx.doi.org/10.1046/j.13652427.1998.00347.x

HILL, BH., HERLIHY, AT., KAUFMANN, PR., STEVENSON, RJ., McCORMICK, FH. and JOHNSON, B., 2000. Use of periphyton assemblage data as an index of biotic integrity. Journal of the North American Benthological Society, vol. 19, no. 1, p. 50-67. http://dx.doi.org/10.2307/1468281

JAMESON, SC., ERDMANN, MV., KARR, JR. and POTTS, KW., 2001. Charting a course toward diagnostic monitoring: a continuing review of coral reef attributes and a research strategy for creating coral reef indexes of biotic integrity. Bulletin of Marine Science, vol. 69, no. 2, p. 701-44.

JEPSON, W., 2005. A disappearing biome? Reconsidering landcover change in the Brazilian savanna. The Geographical Journal, vol. 171 , no. 2, p. 99-111. http://dx.doi.org/10.1111/j.14754959.2005.00153.x

JOY, MK. and DEATH, RG., 2004. Application of the index of biotic integrity methodology to New Zealand freshwater fish communities. Environmental Management, vol. 34, no. 3, p. 415428. PMid:15520898. http://dx.doi.org/10.1007/s00267-004-0083-0

KARR, JR. 1981. Assessment of biotic integrity using fish communities. Fisheries, 6 (6): 21-27.

KARR, JR. and DIONNE, M., 1991. Designing surveys to assess biological integrity in lakes and reservoirs. Biological criteria: research and regulation. Washington: U.S. Environmental Protection Agency. D.C., EPA - 440/ 5-91-005.62-72.

KARR, JR., FAUSCH, KD., ANGERMEIER, PL., YANT, PR. and SCHLOSSER, IJ., 1986. Assessing biological integrity in running water: a method and its rationale. Champaign: Illinois Natural History Survey. 28 p. Special Publication 5.

KENNARD, MJ., ARTHINGTON, AH., PUSEY, BJ. and HARCH, BD., 2005. Are alien fish a reliable indicator of river health? Freshwater Biology, vol. 50, no. 1, p. 174-193. http:// dx.doi.org/10.1111/j.1365-2427.2004.01293.x

KERANS, BL. and KARR, JR., 1994. A benthic index of biotic integrity (B-IBI) for rivers of the Tennesse Valley. Ecological Application, vol. 4, no. 4, p. 768-785. http://dx.doi. org/10.2307/1942007

KIMBERLING, DN., KARR, JR. and FORE, LS., 2001. Measuring human disturbance using terrestrial invertebrates in the shrubsteppe of eastern Washington (USA). Ecological Indicators, vol. 1, no. 2, p. 63-81. http://dx.doi.org/10.1016/S1470-160X(01)00009-7

KLINK, CA. and MACHADO, RB., 2005. Conservation of the Brazilian Cerrado. Conservation Biology, vol. 19, no. 3, p. 707713. http://dx.doi.org/10.1111/j.1523-1739.2005.00702.x

LIBOS, M., ROTUNNO FILHO, OC. and ZEILHOFER, P., 2005. Sensoriamento remoto (SR) e sistema de informações geográficas (SIG) para modelagem de qualidade da água. Estudo de caso: bacia do rio Cuiabá. In Anais XII Simpósio Brasileiro de Sensoriamento Remoto, 2005, Goiânia, p. 2219-2227.

LYONS, J., NAVARRO-PEREZ, S., COCHRAN, PA., SANTANA, E. and GUZMÁN-ARROYO, M., 1995. An Index of Biotic Integrity based on fish assemblages for the conservation of streams and rivers in West-Central Mexico. Conservation Biology, vol. 9, no. 3 , p. $569-584$. 
MAGNUSSON, WE. and MOURÃO, G., 2003. Estatística sem matemática. EDITORA PLANTA, Paraná, p.125.

MEADOR, MR., BROWN, LR. and SHORT, T., 2003. Relations between introduced fish and environmental conditions at large scale geographic. Ecological Indicators, vol. 3, no. 2, p. 81-92. http://dx.doi.org/10.1016/S1470-160X(03)00013-X

MICACCHION, M. 2002. Amphibian index of biotic integrity (AmphIBI) for wetlands. Final Report EPA Grant ${ }^{\circ}$ CD98587501, Ohio.

NIEMI, GJ. and McDONALD, ME., 2004. Application of ecological indicators. Annual Review of Ecology Evolution and Systematics, vol. 35, p. 89-111. http://dx.doi.org/10.1146/annurev. ecolsys.35.112202.130132

OBERDORFF, T. and HUGHES, RM., 1992. Modification of an Index of Biotic Integrity based on fish assemblages to characterize rivers of the Seine basin, France. Hydrobiologia, vol. 228, p. 117130. http://dx.doi.org/10.1007/BF00006200

OBERDORFF, T., PONT, D., HUGUENY, B. and PORCHER, JP., 2002. Development and validation of a fish-based index for the assessment of 'river health' in France. Freshwater Biology, vol. 47, no. 9, p. 1720-1734. http://dx.doi.org/10.1046/j.13652427.2002.00884.x

OLIVEIRA, RS., BEZERRA, L., DAVIDSON, EA., PINTO, F., KLINK, CA., NEPSTAD, DC. and MOREIRA, A., 2005. Deep root function in soil water dynamics in cerrado savannas of central Brazil. Functional Ecology, vol.19, no. 4, p. 574-581. http://dx.doi.org/10.1111/j.1365-2435.2005.01003.x

OVIDIO, M. and PHILIPPART, J., 2002. The impact of small physical obstacles on upstream movements of six species of fish. Hydrobiologia, vol. 483, p. 55-69. http://dx.doi. org/10.1023/A:1021398605520

PAULY, D., CHRISTENSEN, V., GUÉNETTE, S., PITCHER, TJ., SUMAILA, UR., WALTERS, CJ., WATSON, R. and ZELLER, D., 2002. Towards sustainability in world fisheries. Nature, vol. 418, p. 689-695. PMid:12167876. http://dx.doi. org/10.1038/nature01017

PICHON, C., GEORGES, G., BOËT, P., BAUDRY, J., FAURE, T. and GOREAUD, F., 2006. A spatially explicit resource-based approach for managing stream fishes in riverscapes. Environmental Management, vol. 37, no. 3, p. 322-335. PMid:16456624. http:// dx.doi.org/10.1007/s00267-005-0027-3

PRINGLE, C., 2003. What is hydrologic connectivity and why is it ecologically important? Hydrological Processes, vol. 17, no. 13, p. 2685-2689. http://dx.doi.org/10.1002/hyp.5145

RATTER, JA., RIBEIRO, JF. and BRIDGEWATER, S., 1997. The Brazilian Cerrado Vegetation and Threats to its Biodiversity. Annals of Botany, vol. 80, no. 3, p. 223-230. http://dx.doi. org/10.1006/anbo.1997.0469
REIS, R.E., KULLANDER, O. \& FERRARIS JR, C.J. 2003. Check list of the freshwater fishes of South and Central America. EDIPUCRS, Porto Alegre.

ROBINSON, CT., TOCKNER, K. and WARD, JV., 2002. The fauna of dynamic riverine landscapes. Freshwater Biology, vol. 47, no. 4, p. 661-677. http://dx.doi.org/10.1046/j.1365-2427.2002.00921.x

RODRÍGUEZ-OLARTE, D., AMARO, A., CORONEL, J. and TAPHORN, DC., 2006. Integrity of fluvial fish communities is subject to environmental gradients in mountain streams, Sierra de Aroa, north Caribbean coast, Venezuela. Neotropical Ichthyology, vol. 4 , no. 3, p. 319-328.

SCHLOSSER, IJ., 1995. Critical landscape attributes that influence fish population dynamics in headwater streams. Hydrobiologia, vol. 303, p. 71-81. http://dx.doi.org/10.1007/BF00034045

STAUFFER, JC., GOLDSTEIN, RM. and NEWMAN, RM., 2000. Relationship of wooded riparian zones and runoff potential to fish community composition in agricultural streams. Canadian Journal of Fisheries and Aquatic Sciences, vol. 57, no. 2, p. 307316. http://dx.doi.org/10.1139/cjfas-57-2-307

STRIBLING, JB.; JESSUP, BJ.; WHITE, JS., BOWARD, D. and HURD, M. 1998. Development of a benthic index of biotic integrity for Maryland streams. Prepared by Tetra Tech Inc. for the Maryland Department of bNatural Resources, Monitoring and Non-Tidal Assessment division, Annapolis, Maryland, CBWP-EA-98-3.

TOHAM, AK. and TEUGELS, GG., 1999. First data on an Index of Biotic Integrity (IBI) based on fish assemblages for the assessment of the impact of deforestation in a tropical West African river system. Hydrobiologia, vol. 397, p. 29-38.

VUGTEVEEN, P., LEUVEN, RSEW., HUIJBREGTS, MAJ. and LENDERS, HJR., 2006. Redefinition and elaboration of river ecosystem health: perspective for river management. Hydrobiologia, vol. 565, p. 289-308. http://dx.doi.org/10.1007/s10750-005-1920-8

WANTZEN, KM., SIQUEIRA, A., NUNES DA CUNHA, C. and SÁ, MF., 2006. Conservation scheme for forest-stream-ecosystems of the Brazilian Cerrado and similar biomes in the seasonal tropics. Aquatic Conservation, vol. 16, p. 713-732.

WEISBERG, SB., RANASINGHE, JA., SCHAFFNER, LC., DIAZ, RJ., DAUER, DM. and FRITHSEN, JB., 1997. An estuarine benthic index of biotic integrity (B-IBI) for Chesapeake Bay. Estuaries, vol. 20, no. 1, p. 149-58. http://dx.doi.org/10.2307/1352728

WIENS, JA., 2002. Riverine landscapes: taking landscape ecology into the water. Freshwater Biology, vol. 47, no. 4, p. 501-515. http://dx.doi.org/10.1046/j.1365-2427.2002.00887.x

ZAR, JH., 1999. Biostatistical analysis. 4nd ed. New Jersey: Prentice-Hall. 